\title{
The urban community in fifteenth-century Scotland: language, law and political practice
}

\author{
CLAIRE HAWES* \\ Department of History, University of Aberdeen, Old Aberdeen, AB24 3FX, UK
}

\begin{abstract}
The political culture of Scotland's late medieval towns has been neglected in recent scholarship. This article seeks to provoke discussion through an analysis of communitarian language and its use by urban elites in the fifteenth century. The Scottish urban community, as elsewhere, could be positioned as a location, a legal construct and a group of people. This provided the burgh council with a variety of political tools which could be employed - consciously or otherwise - in order to legitimize its authority.
\end{abstract}

The nature of the medieval urban community in Scotland has divided opinion. In her earlier work Elizabeth Ewan argued for a sense of community within the burghs which was characteristic of medieval life, enhanced by the exercise of communal rights and privileges, and which remained unaffected by social inequality. ${ }^{1}$ Whilst acknowledging that towns were demarcated from their surrounding countryside, and that the overlap with the spiritual communities of the parishes would have done much to aid a sense of 'oneness', Patricia Dennison has instead chosen to emphasize exclusion, and argues that medieval society was too stratified and hierarchical for any true communal feeling to take hold across social groups. ${ }^{2}$ Christine Carpenter, meanwhile, writing on English gentry communities, has gone as far as to suggest that historians ought not to use the word at all, due to the 'prelapsarian attitudes' of those who employ it. ${ }^{3}$ If questions of identity are paramount, then the idea of community is indeed problematic; as Carpenter argues, the designation of

* I am very grateful to Jackson Armstrong, Michael H. Brown, Jan Dumolyn, Elizabeth Ewan, Andrew Mackillop, Jacqueline Rose and Phil Withington for their comments on earlier drafts of this article.

${ }^{1}$ E. Ewan, Townlife in Fourteenth-Century Scotland (Edinburgh, 1990), 136-40.

2 E.P. Dennison, 'Power to the people? The myth of the medieval burgh community', in S. Foster, A. Macinnes and R. MacInnes (eds.), Scottish Power Centres (Glasgow, 1998), 100-31.

3 C. Carpenter, 'Gentry and community in medieval England', Journal of British Studies, 33 (1994), 340-80. 
a group as a community can be rather arbitrary, and can suggest a 'sense of belonging' on the part of its members which is not always possible to corroborate with the extant evidence. ${ }^{4}$ It is one thing to argue that because a person lived in close proximity to others she shared with them a set of expectations and assumptions about how things ought to be done, and quite another to attribute to her a particular feeling about her place of residence or her neighbours. ${ }^{5}$ If instead, however, community is taken to be an idea with political force, the focus of the inquiry becomes not which individuals identified with the community, but the range of uses to which community could be put in contemporary political culture. As Phil Withington has argued, the significance of the word is derived from its 'polyvalence, appropriability and capacity for synonymy', rather than any particular set of values, and it is these qualities which made it such a useful idea within the context of urban politics. ${ }^{6}$

There is currently something of a disconnect between the urban history and the political history of late medieval Scotland. Recent scholarship on the former has explored the Scottish burgh by interrogating not only its records, but also a rich variety of material evidence, giving fresh insights into the economic and social history of town life, as well as the relationships cultivated by burghs both within Scotland and without. ${ }^{7}$ The latter has largely remained focused on the perennial question of crown-magnate relations, with even Roland Tanner's study of the Scottish parliament arguing that the burgesses were the 'least obviously political' estate of the three. ${ }^{8}$ While work by Boardman and Booton has gone some way to positioning the medieval burgh of Aberdeen within the broader politics of the realm, the political culture of Scotland's towns remains an

${ }^{4}$ Ibid., 344. Carpenter instead advocates social network analysis as a tool for exploring urban identities. For an extremely helpful overview of the ways in which the idea of community has been understood in a historical context, see P. Withington, 'Introduction', in P. Withington and A. Shepard (eds.), Communities in Early Modern England: Networks, Place, Rhetoric (Manchester, 2000), 1-15.

${ }^{5}$ In fact identity is no less problematic an analytical tool than community. For a discussion, see R. Brubaker and F. Cooper, 'Beyond identity', Theory and Society, 29 (2000), 1-47.

${ }^{6}$ Withington, 'Introduction', 2. What follows has been greatly influenced by Withington's approach. See in particular P. Withington, The Politics of Commonwealth: Citizens and Freemen in Early Modern England (Cambridge, 2005), and 'Public discourse, corporate citizenship and state formation in early modern England', American Historical Review, 112 (2007), 1016-38.

7 An excellent starting point is M. Lynch, M. Spearman and G. Stell (eds.), The Scottish Medieval Town (Edinburgh, 1988). See also the work of Elizabeth Ewan, in particular Townlife; E.J. Cowan and L. Henderson (eds.), A History of Everyday Life in Medieval Scotland, 10001600 (Edinburgh, 2010); Royal Commission on the Ancient and Historical Monuments of Scotland, Tolbooths and Town-Houses: Civic Architecture in Scotland to 1833 (Edinburgh, 1996); E.P. Dennison, D. Ditchburn and M. Lynch (eds.), Aberdeen before 1800: A New History (East Linton, 2002); D. Ditchburn, Scotland and Europe: The Medieval Kingdom and its Contacts with Christendom, 1215-1545, vol. I: Religion, Commerce and Culture, c. 1215-1545 (East Linton, 2001).

8 R. Tanner, The Late Medieval Scottish Parliament: Politics and the Three Estates, 1424-1488 (East Linton, 2001), 268. For a recent overview of the period, see K. Stevenson, Power and Propaganda: Scotland 1306-1488 (Edinburgh, 2014). 
underresearched area. ${ }^{9}$ Such questions have been investigated elsewhere; Susan Reynolds long ago exhorted medieval historians to consider the centrality of contemporary political thought to urban politics. ${ }^{10}$ In Scotland, the evidence does not, however, suggest that such questions would provide a fruitful line of inquiry. The relatively poor survival of the longer runs of records required for diachronic analysis makes the task rather more challenging than might be the case elsewhere. ${ }^{11}$ The most notable exception to this is the Aberdeen burgh council registers, which record a wide variety of business over an extended period of time, and in so doing describe not only the important practices and rituals associated with town governance, but also the legal norms and conceptual tools used by the council to legitimize its decisions. ${ }^{12}$

Perhaps unsurprisingly, the study of communitarian ideas has very often been aided by the analysis of language. ${ }^{13}$ Roger Mason has explored the change in the vocabulary of Scottish political thought over the fifteenth and sixteenth centuries, from medieval expressions of the common good to early modern notions of the commonweal. ${ }^{14}$ John Watts has examined how the idea of 'the commons' was used in English political culture, while the Early Modern Research Group, headed by Mark Knights, has focused upon the development of the concept of commonwealth in England through

${ }^{9} \mathrm{~S}$. Boardman, 'The burgh and the realm', in Dennison, Ditchburn and Lynch (eds.), Aberdeen before 1800, 203-23; H. Booton, 'Burgesses and landed men in north-east Scotland in the later Middle Ages: a study in social interaction', unpublished University of Aberdeen Ph.D. thesis, 1987. The most comprehensive overview is still the introduction in W.C. Dickinson (ed.), Early Records of the Burgh of Aberdeen 1317, 1390-1407 (Edinburgh, 1957), xvii-cli, although the focus is heavily institutional.

${ }^{10} \mathrm{~S}$. Reynolds, 'Medieval urban history and the history of political thought', Urban History Yearbook, 9 (1982), 14-23, at 14.

${ }^{11}$ Fifteenth-century guild court books survive from three towns: E. Gemmill (ed.), Aberdeen Guild Court Records, 1437-1468 (Abdn Guild Recs.) (Edinburgh, 2005); M. Stavert (ed.), The Perth Guildry Book, 1452-1601 (Edinburgh, 1993); E.P.D. Torrie (ed.), The Guild Court Book of Dunfermline, 1433-1597 (Edinburgh, 1986). Further urban records can be found from Ayr, Lanark, Montrose, Newburgh, Peebles and Prestwick. I am grateful to Dr William Hepburn for sharing his thoughts on these.

12 Aberdeen City and Aberdeenshire Archives (ACA), Council, Bailie and Guild Registers (CA). The fifteenth-century entries are covered by vols. 1-7. Digital scans of the original documents can currently be found at www.scotlandsplaces.gov.uk/, accessed 24 Jul. 2016. There are also some fifteenth-century entries from the register of Edinburgh burgh council, copied into later volumes and collected in J.D. Marwick (ed.), Extracts from the Records of the Burgh of Edinburgh (Edin. Recs.), vol. I (Edinburgh, 1869); Edinburgh City Archives (ECA), SL1/1, 1456-1975 town council minutes, vol. 1; National Library of Scotland (NLS), Adv.MS.31.4.9; extracts, sixteenth-century, from the minutes of Edinburgh Town Council, 1442-1579.

${ }^{13}$ C. Fletcher, 'What makes a political language? Key terms, profit and damage in the common petition of the English parliament, 1343-1422', in J. Dumolyn, J. Haemers, H.R. Oliva Herrer and V. Challet (eds.), The Voices of the People in Late Medieval Europe: Communication and Popular Politics (Turnhout, 2014), 91-106, demonstrates the power of corpus linguistics to shed light on medieval political culture.

${ }^{14}$ R. Mason, Kingship and the Commonweal: Political Thought in Renaissance and Reformation Scotland (East Linton, 1998). 
an examination of the contexts in which it is found. ${ }^{15}$ This focus upon language and its uses is firmly grounded in intellectual history, and this has perhaps made it a less than obvious choice for those interested in urban politics. ${ }^{16}$ Yet much is possible when medieval urban records and linguistic methodologies are combined, as the recent political history of Flanders has shown. ${ }^{17}$ Jan Dumolyn argues that legal and theological concepts from princely discourse 'trickled down' into the Flemish towns, shaping what he calls a 'practical theory of political action', and informing contemporary ideologies which were then used by 'lay actors' in urban politics. ${ }^{18}$ In England, as Watts has argued, the discourse of the 'community of the realm', strengthened by the Commons in parliament, could be appropriated to support the popular uprisings of the fourteenth and fifteenth centuries. ${ }^{19}$ The direction of travel of political ideas is difficult to establish for Scotland. The early burghs were founded in the twelfth century by David I, placing Scotland firmly within the general European trend which saw the growth of the communes, and yet documentation for the burghs in this period is scanty. ${ }^{20}$ Richard Oram emphasizes the

$15 \mathrm{~J}$. Watts, 'Public or plebs: the changing meaning of "the commons", 1381-1549', in H. Pryce and J. Watts (eds.), Power and Identity in the Middle Ages: Essays in Memory of Rees Davies (Oxford, 2007), 242-60; M. Knights, 'Towards a social and cultural history of keywords and concepts by the Early Modern Research Group', History of Political Thought, 31 (2010), 42748; G. Burgess and M. Knights et al., 'Commonwealth: the social, cultural, and conceptual contexts of an early modern keyword', Historical Journal, 54 (2011), 659-87.

16 There is a large literature on this subject, and what follows are suggested starting points only. R. Williams, Keywords (London, 1976), informed many later approaches. For discourse analysis, N. Fairclough, Discourse and Social Change (Cambridge, 1992). For the 'Cambridge School', Q. Skinner (ed.), Visions of Politics, vol. I: Regarding Method (Cambridge, 2002); J.G.A. Pocock, 'The concept of a language and the metier d'historien: some considerations on practice', in A. Pagden (ed.), The Languages of Political Theory in Early Modern Europe (Cambridge, 1987), 19-38. For a discussion of Pocock's political languages in the context of medieval Europe, A. Black, 'Political languages in later medieval Europe', in D. Wood (ed.), The Church and Sovereignty c. 590-1918: Essays in Honour of Michael Wilks (Oxford, 1991), 313-28.

${ }^{17}$ In particular the work of Jan Dumolyn and Jelle Haemers. For an explicit discussion of Dumolyn's methodology, see his 'Urban ideologies in later medieval Flanders: towards a methodological framework', in A. Gamberini, J.-P. Genet and A. Zorzi (eds.), The Languages of Political Society: Western Europe, Fourteenth to Seventeenth Centuries (Milan, 2011), 69-96. See also J. Dumolyn, 'Privileges and novelties: the political discourse of the Flemish cities and rural districts in their negotiations with the dukes of Burgundy (1384-1506)', Urban History, 35 (2008), 5-23; and J. Dumolyn and J. Haemers, "'A bad chicken was brooding": subversive speech in late medieval Flanders', Past and Present, 214 (2002), 45-86. C. Liddy, "Bee war of gyle in borugh": taxation and political discourse in late medieval English towns', in Gamberini, Genet and Zorzi (eds.), The Languages of Political Society, 461-85, takes a linguistic approach to English sources.

18 Dumolyn, 'Urban ideologies', 74-5.

19 Watts, 'Public or plebs', 248-9; idem, 'The pressure of the public on later medieval politics', in L. Clark and C. Carpenter (eds.), Political Culture in Late Medieval Britain (Woodbridge, 2004), 159-79, at 170.

${ }^{20}$ For a discussion of the extant evidence, see I. Flett and J. Cripps 'Documentary sources', in Lynch, Spearman and Stell (eds.), The Scottish Medieval Town, 18-41. On the early burghs, R. Oram, Domination and Lordship: Scotland 1070-1230 (Edinburgh, 2011), $265-94$. 
importance of both Flemish and English colonists to the development of the towns, presenting the possibility that political ideas and practices were imported along with skills and expertise. ${ }^{21}$ By the fifteenth century, the bonum commune certainly permeated Scottish princely discourse, and given the position of the burgesses as the third estate in parliament, it is likely that such ideas were also reinforced from above. Unlike in England, however, the Scottish parliament was unicameral and so the discourse of community developed rather differently; by the later fifteenth century, the term appears to have been applied often to the burghs, and very rarely indeed to the kingdom as a whole..$^{22}$ Scotland maintained close links to Flanders and England throughout the medieval period, and although there is little sign in the records of the revolts which shaped the use of communitarian ideas in these polities, there nevertheless existed a public domain in which political authority was asserted and contested. ${ }^{23}$ It is therefore possible that the use of this discourse in the towns was reinforced from multiple directions. Such questions must remain a matter for debate, as the ability to study the 'production, diffusion and reception of ideological discourses by historical actors in clearly defined power relationships', as advocated by Dumolyn, is severely limited by the sources. ${ }^{24}$ Instead, the ways in which community was delineated, controlled and deployed in Scottish towns, and the political ends to which it was then put, can be examined through analysis of the language of the extant council records. ${ }^{25}$ This approach necessarily limits the main focus of the investigation to Aberdeen, and broadens the scope to include spatial, as well as linguistic, formulations of community. ${ }^{26}$ It is suggested here that the Scottish medieval burgh community could be thought of as a location, a legal construct and a group of people, and that the overlap between these elements provided a conceptual space which could be appropriated by those in authority in order to legitimize political decisions and actions.

21 Oram, Domination and Lordship, 281-3; Dickinson (ed.), Early Records, xc-xci. For medieval Scotland's European connections more broadly, see Ditchburn, Scotland and Europe.

22 C. Hawes, 'Community and public authority in later fifteenth-century Scotland', unpublished University of St Andrews Ph.D. thesis, 2015, 95-6.

23 On the public domain, and the place of communitarian discourse within it, see Hawes, 'Community and public authority', passim.

24 Dumolyn, 'Urban ideologies', 71.

25 Such analysis is about to be revolutionized by a project currently underway at the University of Aberdeen: Law in the Aberdeen Council Registers, 1398-1511: Concepts, Practices, Geographies, https: / / aberdeenregisters.org/, accessed 21 Jul. 2016.

26 Space as an analytical tool has also frequently been used within medieval urban history, for example D. Ditchburn, 'Ritual, space and the marriage of James II and Mary of Guelders, 1449', in F. Andrews (ed.), Ritual and Space in the Middle Ages (Donington, 2011), 179-96; L.O. Fradenburg, City, Marriage, Tournament: Arts of Rule in Late Medieval Scotland (Madison, 1991); C. Clarke, Mapping the Medieval City: Space, Place and Identity in Chester, c. 1200-1600 (Cardiff, 2011); P. Arnade, 'City, state and public ritual in the late-medieval Burgundian Netherlands', Comparative Studies in Society and History, 39 (1997), 300-19. 


\section{The community as corporation}

The Latin term communitas was one of several words which, by the later Middle Ages, could be used to designate a corporation which held particular rights and privileges in law. ${ }^{27}$ This idea took its power from the fact that a corporation, such as a burgh, could be simultaneously both a legal construct distinct from its members and the group of men who comprised it. ${ }^{28}$ The corporation, as an abstraction, could not give consent; this had to be done by those present on any given occasion. The corporeal aspect of the communitas was therefore only 'apparent and operative' after the members had come together in congregation, hence the need for the burgh council to consent to decisions affecting the whole community. ${ }^{29}$ The importance of the distinction between the burgesses themselves and the communitas can be seen in the charter evidence from Edinburgh. The standard formula used by the crown in its grants to the burgh, from the reign of David II onwards, was, as in a charter of 1364, 'Know ye that we have given, granted and by this our present charter have confirmed to the burgesses and community of the burgh of Edinburgh. ${ }^{\prime 30}$ The clear distinction made by the crown between burgesses and community recognizes the town both as a group of men and as a corporation. In effect, the king is granting land to the town as embodied by the particular burgesses who constitute it at any given time. He grants both to the men who are there to receive it and to those who will make up the communitas in the future. A charter from 1367, which prohibits fairs being held in Newbattle, draws a similar distinction in referring to the prejudice and hurt of our burgh of Edinburgh and of our burgesses of the same place', instead referring to the corporation as 'burgus' rather than 'communitas'. ${ }^{31}$

R.L.C. Hunter, in one of the very few pieces of work which addresses directly the idea of incorporation in relation to the Scottish burghs, suggests that this developed very differently in Scotland to England. ${ }^{32}$ He argues that in England, by the mid-fifteenth century, the law relating to corporate personality had 'crystallised' into the five 'classic incidents'

$27 \mathrm{~J}$. Canning, 'The corporation in the political thought of the Italian jurists of the thirteenth and fourteenth centuries', History of Political Thought, 1 (1980), 9-32, at 9; A. Black, Political Thought in Europe, 1250-1450 (Cambridge, 1992), 14-41. Canning lists corpus, respublica, populus, civitas, collegium, societas and universitas as possible alternatives.

28 Canning, 'The corporation', 10-14; Dickinson (ed.), Early Records, xlviii-xlix.

${ }^{29}$ Canning, 'The corporation', 14; Dickinson (ed.), Early Records, lxxxviii.

30 J.D. Marwick (ed.), Charters and Other Documents relating to the City of Edinburgh (Edin. Chrs.), Scottish Burgh Records Society (Edinburgh, 1871), 25: 'Sciatis nos dedisse concessisse et hac presenti carta nostra confirmasse Burgensibus et Communitati Burgi de Edynburgh...'.

31 Ibid., 26-7: 'preiudicium ac grauamen Burgi nostri de Edynburgh ac Burgensium nostrorum eiusdem loci...'.

32 R.L.C. Hunter, 'Corporate personality and the Scottish burgh: an historical note', in G.W.S. Barrow (ed.), The Scottish Tradition: Essays in Honour of Ronald Gordon Cant (Edinburgh, 1974), 223-42, at 232. 
of incorporation, which could only be granted explicitly by royal charter. ${ }^{33}$ In contrast, Hunter argues, a high degree of imprecision characterized the language of the Scottish records, which he attributes to a 'lack of legal refinement'. ${ }^{34}$ Hunter's observations on the fluidity of nomenclature in relation to the town and its representatives are undoubtedly correct, and yet the rigidity of terminology which characterized English practice was not typical of medieval towns generally. ${ }^{35}$ The imprecision of the language in which it was expressed was one factor which allowed collective governance to be reproduced across Europe and, as Reynolds argues, by the thirteenth century the various words which described these bodies could be used in reference to the whole community of government and people together, or just the government, or just the community of people whom the government governed'. ${ }^{36}$ If this still pertained to Scotland by the later fifteenth century it is surely because, as in other places, it still worked very well. ${ }^{37}$ Rather than a judgment on the degree of legal 'sophistication' relative to England, what is required is a closer analysis of the linguistic and political contexts and circumstances in which such variations appear, in order to assess the utility of a particular choice.

\section{The community as a group of people}

One of the most noticeable attributes of communitarian terminology found within burgh council minutes is its diversity. Even when simply discussing the burgh as a group of men, there is a range of possible terms which can be employed. 'Burgesses' is the clearest, as it denotes those men who have been admitted to burgess-ship. ${ }^{38}$ An 'outburgess' was a burgess who lived outside the town boundary, drawing a clear spatial distinction. Another collective term is 'neighbours', which often suggests the burgesses as a group, as it is commonly found within statutes which concern either trading privileges or burgess obligations. Occasionally, the word 'commons' can be found performing the same functions as community, also eliding the distinction between the burgesses and the whole population of the town. 'Indwellers' or 'inhabitants' can both usually be taken to mean those non-burgesses who lived within the geographical area of the burgh. These terms had the advantage of being easily contrastable with 'outdwellers', who could be invoked in order to underline the importance

33 Ibid., 231, 237. These incidents are listed as the power to sue and liability to be sued as a body... [the] power to hold landed property, the privilege of using and the power legally to act by a common seal, perpetual succession ... and the power to make by-laws'.

${ }^{34}$ Ibid., 232.

35 As noted by Canning, above, n. 27. See also Black, Political Thought, 118-21.

36 S. Reynolds, Kingdoms and Communities in Western Europe, 900-1300 (Oxford, 1984), 182. See also J. Watts, The Making of Polities: Europe, 1300-1500 (Cambridge, 2009), 98-9.

37 Dickinson (ed.), Early Records, xlix, states that the Scottish medieval burgh can be seen as 'something approaching a corporation', due to its ability to hold property 'for the common good'. On the burgh seals, see l-li in the same volume.

38 For the conditions and processes which relate to this, see Ewan, Townlife, passim. 
of performing designated duties. A statute of 1484, in Aberdeen, ordered that 'all neighbours and inhabitants of this burgh' should have their weapons ready so that they could assist the town's officers in the 'correction of trespassers', and, further, that the people should 'abstract themselves not from their neighbours when they see them ... in point of suppression, and namely by outdwellers of the burgh' ${ }^{39}$ The language makes very clear what is expected from members of the burgh community, and positions them directly against those who are not members. The fact that such a statute had to be enacted at all suggests that the danger from outdwellers was not imminent enough for people to keep their weapons ready as a matter of course, and so this language was employed to reinforce the plea for assistance. It could, in fact, have arisen from a single incident which the council wished to avoid being replicated. Another Aberdeen statute, from 1479, records a grant to Sandy Cowtis of a penny from each house in the town, for mending streets and gates, stating that he should collect 'from each fire house [house with a fireplace] a penny, and of all others, outburgesses and inburgesses and indwellers having chamber or house, a penny', showing that one did not necessarily have to belong to the exclusive group of burgesses in order to be asked to contribute to an enterprise one was likely to benefit from. ${ }^{40}$

A letter from James III to the 'burgesses and community of Edinburgh' in 1472 underlines how intertwined was membership of the community with the status and nature of property ownership. The letter is a licence to fortify the town 'in case our old enemies of England address them to invade'. ${ }^{11}$ The king charges 'all and sundry the burgesses, neighbours and indwellers of the said town, and also them that has lands, annuals or possessions within it' to contribute to the cost of the fortifications 'and that as well the outburgesses and occupiers of the freedom of the said burgh, and persons having lands or annuals within it, contribute as indwellers and inhabitants thareof' ${ }^{42}$ There is a very clear sense that those who have something to protect must contribute towards the protection of it, regardless of their status in relation to the community. This demonstrates how the concept of community could expand to include people beyond the physical boundaries of the town when the situation required. The distinction made between burgesses and community would, in this instance, have worked to ensure that any 'occupiers of the freedom' who might have disagreed with the idea that they were part of the community would nevertheless have had to make a contribution. Likewise, the burgesses could be described as 'freemen' which again could be contrasted with

${ }^{39}$ ACA/CA 1/1/6/824-5; J. Stuart (ed.), Extracts from the Council Register of the Burgh of Aberdeen (Abdn Counc.), vol. I (Edinburgh, 1871), 40.

40 ACA/CA 1/1/6/599; Abdn Counc., 37.

${ }^{41}$ Edin. Chrs., 134.

42 Ibid., 134-5. 
'unfreemen'. ${ }^{43}$ The discourse of urban freedom in medieval Scotland is one which also deserves further exploration, but here it is sufficient to note that it could similarly be used to frame the community in a way appropriate to the circumstances. ${ }^{44}$ In Aberdeen, in 1442, it was ordained that 'all the community, as well unfree as free men, be sworn to rise with the alderman in the defence of the town and of the neighbours of the town. And whoever will not rise, and absents him[self] wilfully, he shall tyne [lose] his freedom and be banished out of the town', indicating that the unfree could be included within the community if it was thought necessary by the council. ${ }^{45}$

\section{Summoning the community}

Once the burgh council had taken decisions they had to be publicized, and it was the town bellman who served this function. In 1490, Edinburgh council recorded that they would 'cause the bellman with the handbell [to] pass through the town warning all the neighbours that such victuals and timber are to be sold of such a price', and in 1479, the bellman was ordered to 'warn all the neighbours thereto in the tolbooth, and in no other place', to notify them of goods coming into the city via the port of Leith. ${ }^{46}$ The sound of the bell echoed throughout the burgh, and was closely tied to the decision-making processes of the burgesses, and to their public assertion of authority. In 1481, a new bellman was appointed by the burgh council in Aberdeen. The community was summoned to the tolbooth by an interim bellman to choose someone 'most habit [suitable] and profitable for the town'. Andrew Murray stepped forward and 'in presence of them all' offered five marks yearly 'to the common profit of the town'. As no one else was willing to give as much, the alderman presented the bell to Murray 'in the name of the town and of the community' and chose him, 'for all the days of his life, common bellman, with the consent of the baillies, council and community being present for the time' ${ }^{47}$ It is clear that convening the council in the tolbooth was necessary for the legitimate bestowal of authority, although this public appointment to the office of 'bellmanship' has the sense of a purely ceremonial occasion. Perhaps, as no one else came forward for the position, Murray's acceptance was something of a foregone conclusion. While the summoning of the community adds legitimacy, and possibly a festive air, to the proceedings, it may be that the number of people who actually attended was not particularly relevant to the business

${ }^{43}$ For the freedoms and privileges pertaining to the burgesses, see Dickinson (ed.), Early Records, xxxv-xl; lxxiii-lxxvi.

${ }^{44}$ For its use in early modern England, see J. Barry, 'Civility and civic culture in early modern England: the meanings of urban freedom', in P. Burke, B. Harrison and P. Slack (eds.), Civil Histories: Essays Presented to Sir Keith Thomas (Oxford, 2000), 181-96.

45 Abdn Guild Recs., 67.

46 NLS/Adv.MS.31.4.9, 132; Edin. Recs., 59, 37.

47 ACA/CA 1/1/7/724-5; Abdn Counc., 30-1, which erroneously dates this entry to 1471. 
at hand. Although the consent of the community was required for the appointment to be official, this could potentially be achieved with a small number of people physically present. ${ }^{48}$ It was, after all, the alderman in the name of the community who had the authority to appoint Murray to the position.

This example can be usefully contrasted with another, from 1487, when James III wrote to 'the council and community' of Aberdeen regarding a complaint made against the alderman, Sir John Rutherford of Tarland, by Gilbert Menzies. ${ }^{49}$ The letter is long and copied into the record in full, again preceded by a description of the bellman passing through the town, 'charging the whole council and community to compear [appear] within their tolbooth to hear our sovereign lord's letters and give their answer thereupon' ${ }^{50}$ In the letter, the king relates how Menzies complained to him 'on behalf of ... the whole body of the town', that Rutherford - described by the king as 'our beloved familiar servant' - was being a 'masterful oppressor' of the king's lieges, that due to Rutherford's oppression 'no merchant may live within [the] said burgh', and that Rutherford did not hold the office with the consent of the burgesses, but 'by the election of a few simple [low] persons, his kinsmen'. ${ }^{51}$ In response, the king commanded the burgesses to 'pass together to your tolbooth and advisedly have an eye to the common profit of our said burgh'. They were to gather information on the matter relating to Rutherford and decide if it 'be made of verity, and of your mind and will, or nocht', and thereafter 'send your mind to us'. Using this information, 'upon diverse things that are done contrary [to] the common profit of our said burgh', the king would then take action. In the meantime 'you and each one of you answer and obey to our said servant, as your alderman, in all things' ${ }^{52}$ While the king was ostensibly commanding the burgh council to investigate the matter themselves, it is perfectly clear that he expected them to exonerate Rutherford of any wrongdoing. He makes his personal connection to the knight explicit in his repeated use of the phrase 'our servant', and calls him 'your alderman' on two occasions. If there were any doubt remaining, the letter carries the implicit threat that the king will be asking Rutherford directly about what has been happening, and that if he finds it to be 'contrary to the common profit', by which he almost certainly means his own wishes, he will take measures to 'make the same be reformed'. It is recorded underneath the letter that after it was 'openly read, heard, seen and understood', the undersigned members of the council decided that 'they gave never power, command, nor commission' to Menzies, nor any others, to give any bill of

\footnotetext{
48 An ordinance of 1446 stated that at least 12 members of the council should be present for business affecting the community. ACA/CA 1/1/5/722; Abdn Guild Recs., 112.

49 ACA/CA 1/1/7/34-36; Abdn Counc., 42-3. For a very brief discussion of Rutherford's career, see Booton, 'Burgesses and landed men', 305.

50 ACA/CA 1/1/7/34; Abdn Counc., 42.

51 ACA/CA 1/1/7/ 35; Abdn Counc., 42-3.

52 ACA/CA 1/1/7/35; Abdn Counc., 43.
} 
complaint, and declared the allegations against Rutherford untrue. Finally, they stated that Rutherford 'made no oppression within the said burgh upon no man'. ${ }^{53}$ There are 99 names attached to this declaration. Although the burgh community is summoned in the same way to the same location, this dispute is evidently an entirely different matter to the selection of a bellman. Whatever the events which led to Menzies' accusation, and however the king had become involved, a swift and united reaction was called for from the council. A great many members of the community not only came to the tolbooth to attest to Rutherford's version of the story, but were understandably keen that they should have been recorded as having done so. In this instance, the consent of the community was granted not simply symbolically, through the alderman, but by a very large proportion indeed of the actual persons who comprised it. ${ }^{54}$ The community was, in effect, represented by whomever was present in the tolbooth when a particular decision was taken.

\section{The town as community}

The town itself could also function in this way, as a clearly defined space in which the communitas existed. In 1461, an Aberdeen statute recorded that any man 'of state higher or lower, dwelling within this burgh' who did not pay his rent, thereby causing 'hindering or prejudice to the town', would not be chosen to bear office 'until the time that he frees himself and keeps the town unscathed anent [in relation to] the king, and all other men, of all debts and charges owed by him'. ${ }^{55}$ Here can be seen the association of the town with the collective financial interests of the men within it. It is prejudice to the town which was to be avoided and the town which was to remain in the king's good graces by ensuring that people paid their dues. It can be inferred from the penalty of loss of office that those who were considered to comprise the town were burgesses only, as it was only they who were entitled to hold office within the burgh. As it was likely to be the other burgesses who had to make up any shortfall to avoid royal displeasure, attaching the payment of rent to the good of the town demonstrates not only the deft employment of communitarian language to reinforce the decision, but also the need to be seen to place a high value on the communal defence of shared interests, and to attach importance to participation in the governance of the burgh. An even more strident example of this requirement can be found in an Aberdeen statute of 1444. It states that 'for the common good and quiet of this town' all the 'indwellers

53 ACA/CA 1/1/7/35-6; Abdn Counc., 44.

54 For an estimate of the burgess population, see M. Lynch and H. M. Dingwall, 'Elite society in town and country', in Dennison, Ditchburn and Lynch (eds.), Aberdeen before 1800, 185 , which equates burgesses to taxpayers, and suggest an average of 320 between the years 1448 and 1468. On urban populations more broadly, Dickinson (ed.), Early Records, xlv-xlvii.

55 ACA/CA 1/1/5(2)/824; Abdn Counc., 22 
and inhabitants' of the burgh were to assist the alderman and officers to uphold the law and punish trespassers. Whoever did the contrary was to be held as a 'rebel against the town' and the 'goodmen' of the town would write to the king under the common seal to have the rebels punished by him. In addition, all such rebels were to be excluded from all 'takes, profits, offices and worship of this town' ${ }^{56}$ The idea of the burgh as a corporation was one which had a high degree of utility in this context; detrimental actions could be cast as rebellion against the town itself, rather than as contrary to the interests of particular individuals. The role and exercise of royal authority within the burghs remains an underexplored area, but the threat of punishment by the king is unusual, and is suggestive of an ability on the part of the burgh community to appeal directly to the king's judgment. ${ }^{57}$ That the language of rebellion is harnessed to this purpose is perhaps not accidental.

\section{The common profit}

The urban community could also find expression in the notion of the common good. ${ }^{58}$ This ubiquitous political idea proved to be easily adaptable to the requirements of urban politics, and in particular guild politics. ${ }^{59}$ In a culture which relied for its status upon economic success, and in which that success was achieved through collective action, a concept which conveyed both the Aristotelian sense of group benefit or advantage and also the sense of monetary profit could be used to position a variety of political actions within the context of the good of the community, and gave a particular legitimacy to those that generated revenue for the community concerned. This dual sense can be found conveyed by a range of keywords based around good, profit, utility and welfare, and connected to the common financial resources of the town, although 'profit' is by far the most frequently used. In Dunfermline, in 1464, the guild court stated that ' for the pleasure of God almighty and common profit of the said burgh, that in time coming for ever more, the market day will be on Saturday and that no market be held within the said burgh upon Sunday nor yet on no festival day'. ${ }^{60}$ This parallels a similar statute in Perth, from 1462, which stated that 'in the honour of God, our Lady and St John, and for the welfare of merchants, that no merchantman nor other man buy wool, hide nor skin upon the Sunday' ${ }^{61}$ While these examples clearly suggest a preoccupation

56 ACA/CA 1/1/5(2)/691; Abdn Counc., 12.

57 For the evolution of jurisdictional relationship between crown, town and guild see Dickinson (ed.), Early Records, lxix-xc.

58 This is a point made in Dumolyn, 'Urban ideologies', 84-9. The following draws upon his approach.

59 See M.S. Kempshall, The Common Good in Late Medieval Political Thought (Oxford, 1999), for its development.

60 Torrie (ed.), Guild Court Book of Dunfermline, 19.

${ }^{61}$ Stavert (ed.), Perth Guildry Book, 32. 
with the spiritual welfare of the guild members the decisions were made, at least in part, to prevent some of them from profiting at the expense of others by trading illegally. ${ }^{62}$ An Edinburgh statute from 1490 states that the council's decision to order the treasurer of the town to buy victuals and timber coming into the harbour was, on the one hand, 'for the common profit of the town and inhabitants thereof' and, on the other, 'for the behuif [benefit], utility and profit of the neighbours of the town' ${ }^{63} \mathrm{~A}$ raft of measures to protect the concerns of the burgh community can be found in the Aberdeen guild records of 1441 . For the 'common profit' of the town it was 'ordained and decreet... by the alderman ... and the whole common council that might be gotten present in the town' that no 'gentle men of the country' were to have income from the rental of fishings or property in the town if they 'come to dwell within the burgh', and that 'merchantmen or neighbours' could only receive such income if they came to live in the burgh 'continually' ${ }^{64}$ The same year, another entry recorded that 'be the advice of the whole council, for the common good of the whole community of this burgh', no fleshers nor any other man, 'neighbour nor unfreeman', were to buy any fish before it reached the market, nor 'tap again at a dearth to the commons any manner of fish while the light of the day be past'. ${ }^{65}$ To 'tap again' was to re-sell, a proscribed activity which the council had to deal with regularly. ${ }^{66}$ Highlighting the 'dearth to the commons', whether this is taken to mean the burgess community or the whole population, puts transgressors firmly outside the group. In each example, the common good is being used to reinforce the importance of the economic measures enacted, and renders the interests of the council as synonymous with the interests of the burgesses, or even the town, as a whole.

A further example, from Edinburgh in 1478, shows that the common good could also encompass the burgh's financial resources. The statute states that 'all the persons that has any of the common good in their hands... [should] come to the tolbooth on Tuesday next to come, in presence of the whole town . . and hear the account of the town' ${ }^{67}$ Another example can be found in 1445, when Aberdeen guild members were warned that 'if any freemen of this town sell to... men of Dundee or of Perth ... they shall pay 40s unforgiven to the common profit of this town' ${ }^{6}{ }^{68}$ Both Aberdeen and Edinburgh had (and still have) a common good fund, which is referred to throughout the records, and in the contexts in which it is mentioned the distinction between the money itself and the welfare of the

62 On the ways in which Christian practices reinforced the economic functions of craft guilds, see G. Richardson, 'Craft guilds and Christianity in late medieval England: a rational choice analysis', Rationality and Society, 17 (2005), 139-89.

63 ECA/SL1/1, 35; Edin. Recs., 59.

64 ACA/CA 1/1/5/1/562; Abdn Guild Recs., 63.

65 ACA/CA $1 / 1 / 4 / 252$.

66 Ewan, Townlife, 66.

67 NLS/Adv.MS.31.4.9, 94; Edin. Recs., 36.

68 Abdn Guild Recs., 100. 
town can become blurred. ${ }^{69}$ The communal nature of the town's resources comes through strongly throughout the Aberdeen council minutes, where references can be found to the common rental, common work and common purse, as well as the common good and common profit. ${ }^{70}$ Designating funds as communal was useful when managing the assets of a communitas, as it allowed the council to claim legitimate action very easily indeed, and to pursue debts with the moral force of the community behind them. These examples represent only a small selection of the contexts in which such language can be found, but it is clear that the idea of the common good was malleable enough to be used for connecting trading sanctions to Christian practice, in the defence of burgh privileges, as justification for the enforcement of penalties for wrongdoers within the burgh and as a description of the town's communal funds. In each instance, the good of the whole community is invoked regardless of the extent to which everyone in the town would benefit from the suggested measures and it could, in fact, be reinforcing the privileges of a very few.

\section{Conclusion}

Two issues arise from this evidence. The first concerns the relationship of the council to the burgesses as a group and to the inhabitants of the town more generally; to what extent was the council actually working towards the common good? The community referred to was often that denoted by communitas - those who comprised the corporation itself - yet it could nevertheless be applied much more broadly in certain circumstances. Conversely, community was not the only word which identified the burgesses as a collective. Other terms, such as neighbours, freemen or commons could be used, and conflating the interests of the burgesses with those of the town itself was also not unusual. Given that the burgh was an important source of revenue for the crown, and that the town's prosperity relied upon commercial activity, the good of the burgesses was in fact synonymous with the good of the burgh in many, quite tangible, respects, and the defence of their privileges necessary to its survival. Whether or not the council actually had the greater good in mind when taking decisions, communitarian rhetoric provided a very powerful way in which the council could legitimize its authority. ${ }^{71}$ Further, as Quentin Skinner has argued, any language consistently employed in this way must eventually circumscribe the range of legitimate actions

69 Dickinson (ed.), Early Records, cxv.

70 For example Abdn Guild Recs., 64 (werk), 65 (purs), 70 (rentaile).

71 This is an argument first made by Quentin Skinner in 'The principles and practice of opposition: the case of Bolingbroke vs. Walpole', in N. McKendrick (ed.), Historical Perspectives: Studies in English Thought and Society in Honour of J.H. Plumb (London, 1974), 93-128. John Watts makes the same case, in the context of fifteenth-century politics, in 'Ideas, principles and politics', in A.J. Pollard (ed.), The Wars of the Roses (Basingstoke, 1995), 117. 
available. ${ }^{72}$ If the council wished to claim that its actions were taken for the good of all it had to take actions which publicly demonstrated this, in order for the justifications to remain relevant and credible over a sustained period of time. If they were neither relevant nor credible there would presumably be no point in making them. This is why it was so important that the council had a degree of control over whom, or indeed what, the community was perceived to be. Because the burgesses and communitas were synonymous, the particular men who sat on the council at any given moment could claim to be acting in the interests of all the burgesses, and therefore the whole community. Sometimes the council members may in fact have been attempting to do this and sometimes they may not, but the language could be used to justify either possibility, and it lent a certain weight to the actions of the council which would otherwise have been lacking. The flexibility of the terminology allowed the burgh council to include within or exclude from the community unfreemen, outdwellers, outburgesses, and therefore anyone who could be made to fit one of these categories. Outdwellers in particular were used to justify actions, often with regard to law and order.

The second issue arises over the level of intention which can be attributed to the language found within the records ${ }^{73}$ First, there are questions regarding the extent to which the record truly reflected the meeting of the council. This is, in fact, less important than how the council chose to record its meeting. These documents were the official record of the burgh corporation; decisions taken by the council were recorded within the registers and then read aloud by the bellman in order to publicize them to the burgh inhabitants. If we wish to recover the ideas which underpinned urban politics, the vocabulary of the council registers is perfectly placed to provide this. Secondly, questions arise as to the extent to which the employment of communitarian language can be said to be intentional on the part of the council. Again, it is not necessary to assume conscious use of a phrase in order for it to be performing the function of justifying an action. There may have been instances in which the common good was invoked with the intent to legitimize a certain decision, while other uses may have been more instinctive. As will be clear from the above examples, however, such language appeared only when the council, or guild, was discussing matters relating to the governance, defence and commercial regulation of the communitas itself, when it was imperative that the appearance of consensus be demonstrated. By availing themselves of these ideas, the councillors were able to carry out their important and lucrative business in an efficient and workable manner. In contrast, such language can rarely be found when the burgh was engaged in interactions with an individual, as can be seen in both the judicial records of the bailie courts, and the

72 Q. Skinner, 'The idea of a cultural lexicon', in Skinner, Visions of Politics, 173-4.

73 This discussion is informed by Q. Skinner, 'Motives, intentions and interpretation', in Skinner, Visions of Politics, 90-102. 
copies of letters sent to members of the nobility. ${ }^{74}$ Harnessing the rhetoric of the common good was only necessary or, presumably, effective, when attempting to mobilize the town as a whole, even though the consent of the community, however defined, would always have been necessary for legitimate action.

The urban community in fifteenth-century Scotland was not a feeling, then, but an idea. It was a powerful construct which could encompass the legal concept of communitas, the people who lived within the burgh, and the town as a space, providing a range of alternatives which could be shaped to fit the circumstances. It allowed the council to promote and defend communal interests, justify the exclusion of those outwith the community, and position the actions of a particular group in relation to the welfare of the whole town, all the while claiming the moral authority of the common profit. It is no longer credible to treat Scotland's medieval towns as somehow apolitical. The evidence clearly demonstrates that urban elites were as adept as their courtly counterparts in wielding the political tools available to them, and that they did so as a matter of course. Their place in the politics of the realm is therefore an area urgently in need of scholarly attention. Other political discourses, such as those of freedom, advice and kinship, also informed the quotidian work of the council, in the regulation of property, finance and disagreements between neighbours, and there remain many unanswered questions about their function also. In addition, the level of political acumen displayed by Scottish merchants - whether as traders or ambassadors - certainly shaped their dealings with counterparts in England, Flanders and beyond, and this evidence suggests a new lens through which to view these interactions. Finally, it might be expected that the rhetoric of community could also be harnessed by those living within the burgh in order to negotiate with the council. The Aberdeen registers provide our best hope of answering this question for fifteenth-century Scotland, and it should become significantly easier to address over the next few years.

${ }^{74}$ On the jurisdiction of the bailie courts, see Dickinson (ed.), Early Records, cxv-cxvii. 